\title{
Histone deacetylase 3 (HDAC3) activity is regulated by interaction with protein serine/threonine phosphatase 4
}

\author{
Xiaohong Zhang, ${ }^{1,4}$ Yukiyasu Ozawa, ${ }^{1,4}$ Heehyoung Lee, ${ }^{1}$ Yu-Der Wen, ${ }^{1}$ Tse-Hua Tan, ${ }^{2}$ \\ Brian E. Wadzinski, ${ }^{3}$ and Edward Seto ${ }^{1,5}$ \\ ${ }^{1}$ H. Lee Moffitt Cancer Center and Research Institute, Tampa, Florida 33612, USA; ${ }^{2}$ Department of Immunology, Baylor \\ College of Medicine, Houston, Texas 77030, USA; ${ }^{3}$ Department of Pharmacology, Vanderbilt University Medical Center, \\ Nashville, Tennessee 37232, USA
}

Histone deacetylase 3 (HDAC3) is one of four members of the human class I HDACs that regulates gene expression by deacetylation of histones and nonhistone proteins. Early studies have suggested that HDAC3 activity is regulated by association with the corepressors N-CoR and SMRT. Here we demonstrate that, in addition to protein-protein interactions with NCoR/SMRT, the activity of HDAC3 is regulated by both phosphorylation and dephosphorylation. A protein kinase CK2 phosphoacceptor site in the HDAC3 protein was identified at position Ser ${ }^{424}$, which is a nonconserved residue among the class I HDACs. Mutation of this residue was found to reduce deacetylase activity. Interestingly, unlike other class I HDACs, HDAC3 uniquely copurifies with the catalytic and regulatory subunits of the protein serine/threonine phosphatase 4 complex $\left(P P 4_{c} / P P 4_{R 1}\right)$. Furthermore, HDAC3 complexes displayed protein phosphatase activity and a series of subsequent mutational analyses revealed that the $N$ terminus of HDAC3 (residues 1-122) was both necessary and sufficient for HDAC3-PP4 $4_{c}$ interactions. Significantly, both overexpression and siRNA knock-down approaches, and analysis of cells devoid of PP4 $4_{c}$, unequivocally show that HDAC3 activity is inversely proportional to the cellular abundance of PP4 ${ }_{c}$. These findings therefore further highlight the importance of protein-protein interactions and extend the significance of dephosphorylation in the regulation of HDAC activity, as well as present a novel alternative pathway by which HDAC3 activity is regulated.

[Keywords: HDAC3; histone deacetylation; protein phosphatase; PP4]

Received December 2, 2004; revised version accepted February 7, 2005.

Histone deacetylases (HDACs) are enzymes that catalyze the removal of acetyl groups from lysine residues in histones and nonhistone proteins. They play a pivotal role in transcriptional regulation and most likely in all biological processes in eukaryotes that involve chromatin. Many studies have suggested that HDACs regulate cell cycle progression, cell proliferation, and differentiation (for review, see Marks et al. 2001, 2003, 2004; Kelly et al. 2002; Thiagalingam et al. 2003; Yang and Seto 2003). In addition, results from several studies have provided strong evidence of a link between HDACs and human cancer (e.g., Brehm et al. 1998; Gelmetti et al. 1998; Grignani et al. 1998; Lin et al. 1998; Lutterbach et al. 1998; Magnaghi-Jaulin et al. 1998; Guidez et al. 2000; Juan et al. 2000; Luo et al. 2000, 2001; Amann et al. 2001; Vaziri et al. 2001; Durst et al. 2003).

The human class I HDACs, which possess homology to the yeast RPD3 protein, include HDAC1, HDAC2,

\footnotetext{
${ }^{4}$ These authors contributed equally to this work.

${ }^{5}$ Corresponding author.

E-MAIL setoe@moffitt.usf.edu; FAX (813) 979-7264.

Article and publication are at http://www.genesdev.org/cgi/doi/10.1101/ gad. 1286005
}

HDAC3, and HDAC8 (for review, see Yang and Seto 2003; Thiagalingam et al. 2003; Marks et al. 2004). Historically, HDAC1 and HDAC2 were the first two HDACs identified and cloned in humans (Taunton et al. 1996; Yang et al. 1996). HDAC3 was subsequently discovered by screening the NCBI expressed sequence tag database for genes that encode proteins similar to yeast RPD3, but distinct from HDAC1 and HDAC2 (Yang et al. 1997; Emiliani et al. 1998). HDAC3 was also independently identified in PHA-activated T cells using mRNA differential display (Dangond et al. 1998). The predicted amino acid sequence of HDAC3 has an open reading frame of 428 residues with a theoretical molecular mass of $\sim 49$ kDa (Yang et al. 1997; Dangond et al. 1998; Emiliani et al. 1998). The protein is conserved across many species and is ubiquitously expressed in a wide variety of human cell lines and tissues (e.g., Emiliani et al. 1998; Johnson et al. 1998; Lu and Horvitz 1998; Shi and Mello 1998; Dangond et al. 1999; Mahlknecht et al. 1999; Strausberg et al. 2002). HDAC3 is located in both the nucleus and in the cytoplasm and can self-associate to form dimers and trimers in vitro and in vivo (Guenther et al. 2002; Yang et al. 2002). Similar to most if not all 
class I HDACs, HDAC3 represses transcription when directed to promoter regions by serving as a corepressor (Yang et al. 1997). The chief targets of HDAC3 are nuclear hormone receptor-regulated and growth-regulated genes (Ishizuka and Lazar 2003; Zhang et al. 2004).

A major breakthrough in our understanding of the regulation and the mechanisms underlying HDAC3 function came from the isolation of a large multi-subunit protein complex containing HDAC3, the nuclear receptor corepressor ( $\mathrm{N}-\mathrm{CoR})$, the silencing mediator for retinoid and thyroid receptors (SMRT), transducin- $\beta$-like protein (TBL1), G-protein pathway suppressor 2 (GPS2), and other factors that have yet to be characterized (Guenther et al. 2000; Li et al. 2000; Underhill et al. 2000; Wen et al. 2000; Zhang et al. 2002; Yoon et al. 2003). N-CoR/SMRT recruits HDAC3 in order to serve as effective corepressors of DNA-bound unliganded nuclear hormone receptors and many other transcription factors including Rev-Erb, COUP-TF, DAX1, MAD, and Pit-1 (Urnov et al. 2000; Jepsen and Rosenfeld 2002). Interestingly, N-CoR and SMRT function not merely as platforms for recruitment of HDAC3 but also directly stimulate HDAC3 enzymatic activity (Wen et al. 2000; Guenther et al. 2001; Zhang et al. 2002).

Although association with N-CoR/SMRT is a principal regulatory mechanism of HDAC3 activity, we have found that the activity of HDAC3, like that of other class I HDACs, is also potentially regulated by phosphorylation (Tsai and Seto 2002). Here we show that the protein kinase CK2 phosphorylates HDAC3 and alters its enzymatic activity. We also report the identification of novel components of the HDAC3 complex and show that the proteins previously designated as p35 and p125 (Wen et al. 2000) are the catalytic and regulatory subunits, respectively, of protein phosphatase 4 (PP4). These new findings suggest that phosphorylation/dephosphorylation is a key determinant of HDAC3 activity.

The $35-k D a$ catalytic subunit of PP4 (PP4 $)$, also known as PPX, is a highly conserved carboxymethylated protein that belongs to the PP2A family of serine/threonine protein phosphatases. Genomic organization of the human $\mathrm{PP}_{c}$ gene suggests a common ancestry with PP2A (Huang et al. 1997). Although 65\% identical to the catalytic subunit of $\mathrm{PP}_{2} \mathrm{~A}_{\mathrm{c}}, \mathrm{PP} 4_{\mathrm{c}}$ does not associate with the $65-\mathrm{kDa}$ regulatory subunit of PP2A (Brewis et al. 1993; Kloeker and Wadzinski 1999). Instead, PP4 ciates with two other regulatory subunits, the 120-125kDa PP4 $4_{\mathrm{R} 1}$ (Kloeker and Wadzinski 1999) and the 50-kDa $\mathrm{PP}_{\mathrm{R} 2}$ (Hastie et al. 2000). A possible isoform of $\mathrm{PP} 4_{\mathrm{R} 1}$ is abundantly expressed in human mesangial cells (Wada et al. 2001). Currently, very little is known about the precise biological functions of PP4. Although some reports have implicated PP4 in the nucleation, growth, and stabilization of microtubules at centrosomes/spindle bodies during cell division (Brewis et al. 1993; Helps et al. 1998; Hastie et al. 2000; Sumiyoshi et al. 2002), the physiological substrates for PP4 have yet to be identified. Here, we present sound evidence that PP4 interacts specifically with HDAC3 and that HDAC3 is a natural substrate of PP4. Consistent with their ability to interact, PP4 can dramatically alter the deacetylase activity of HDAC3. Hence, our results provide the first identification of a protein phosphatase that regulates HDAC3 activity.

\section{Results}

Phosphorylation of HDAC3 on Ser 424

To determine whether HDAC3 is phosphorylated in vivo, we prepared cellular extracts from ${ }^{32} \mathrm{P}$-labeled HeLa cells expressing Flag-HDAC3 and immunoprecipitated the protein with anti-Flag antibodies under high stringency conditions. Immunoprecipitated proteins were resolved on SDS-polyacrylamide gels. As a negative control, an immunoprecipitation was carried out sideby-side with metabolically labeled extracts prepared from HeLa cells expressing the Flag epitope. As shown in Figure 1A (top panel, lane 2), Flag-HDAC3 is detectable as a phosphorylated protein in vivo. The in vivo labeling of Flag-HDAC3 was then repeated, and the phosphorylated product was purified from the SDS gel. Using partial acid hydrolysis, followed by two-dimensional thin layer electrophoresis of the labeled phosphoamino acid, the presence of phosphoserine, but neither phosphothreonine nor phosphotyrosine, was unambiguously identified in HDAC3 (Fig. 1B).

To show that the native HDAC3 protein is phosphorylated on serine, HDAC3 was immunoprecipitated from extracts of HeLa cells using anti-HDAC3 antibodies and immunoblotted with anti-phosphoserine antibodies (Fig. 1C, lane 2). As a negative control, a sample precipitated with preimmune sera was treated identically on the same blot (Fig. 1C, lane 1). Similar to our findings with overexpression of epitope-tagged HDAC3, endogenous HDAC3 was, indeed, phosphorylated on serine.

To identify the phosphorylated serine residue on HDAC3, we first compared an in vivo labeled, immunoprecipitated C-terminal deletion HDAC3 mutant (1-401) to wild-type protein. As shown in Figure 1A, a truncation at the extreme $\mathrm{C}$ terminus of HDAC3 (residues $402-$ 428) completely abolishes HDAC3 phosphorylation (top panel, lane 4). Sequence analysis revealed that two potential serine phosphorylation sites, $\mathrm{Ser}^{405}$ and $\mathrm{Ser}^{424}$, are located in this truncated region (Fig. 1D). Both of these putative HDAC3 phosphorylation sites are conserved between different species, but not among the different class I HDACs. In a subsequent analysis of an artificial neural network predictor of phosphorylation sites (http://www.cbs.dtu.dk/services/NetPhos; Blom et al. 1999), the $\operatorname{Ser}^{424}$ residue received a score of 0.989, strongly indicating that it is a genuine phosphorylation site. To confirm this, we tested an S424A mutant under the same phosphorylation assay conditions used for wild-type HDAC3 in vivo, and observed a dramatic reduction in phosphorylation levels (Fig. 1A, top panel, lane 3).

\section{Protein kinase CK2 phosphorylates HDAC3 $\mathrm{Ser}^{424}$}

The HDAC3 $\mathrm{Ser}^{424}$ residue lies within a protein kinase CK2 recognition motif (X[S/T]XX[D/E]). To determine if 
A

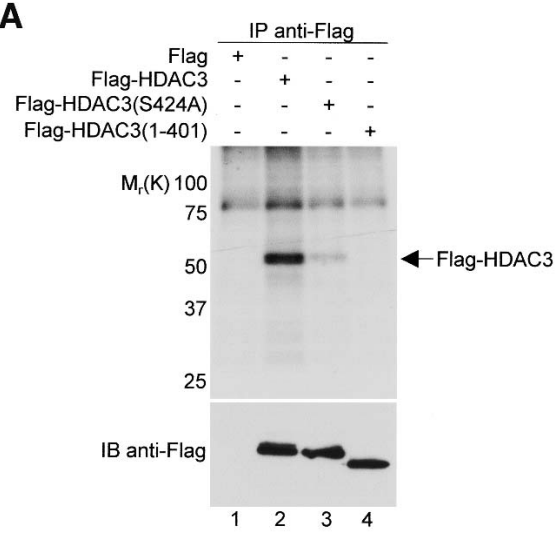

B

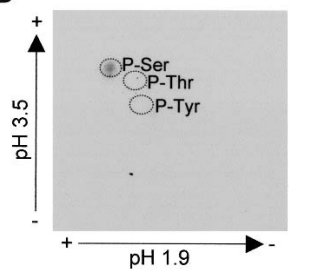

C

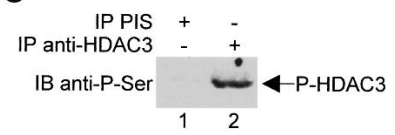

IB anti-HDAC3 $\stackrel{\text { input }}{\longrightarrow} \longrightarrow$ HDAC3

Figure 1. In vivo phosphorylation of $\operatorname{Ser}^{424}$ on HDAC3. (A) HeLa cells were transfected with Flag control vector or with constructs expressing either wild-type or mutant Flag-HDAC3 and were then labeled with ${ }^{32} \mathrm{P}$-orthophosphate for $4 \mathrm{~h}$ at $37^{\circ} \mathrm{C}$. Cell extracts were immunoprecipitated (IP) with antiFlag antibody under high-stringency conditions, and immunoprecipitates were resolved by SDS-PAGE. (Top panel) Phosphoproteins were visualized by autoradiography. Molecular weight markers positions are indicated on the left. (Bottom panel) Immunoprecipitates were immunoblotted (IB) with anti-Flag antibodies to control for expression efficiency in lanes 2-4. (B) Immunoprecipitated and radiolabeled Flag-HDAC3 was excised from an SDS gel, subjected to partial acid hydrolysis and analyzed by cellulose thin-layer chromatography. $(C)$ HeLa cell extracts were either immunoprecipitated with preimmune sera or anti-HDAC3 antibodies and then immunoblotted with anti-phosphoserine antibodies (top panel) or directly immunoblotted with anti-HDAC3 antibodies (bottom panel). (D) Amino acid sequence of the extreme Cterminal end (residues 401-428) of human HDAC3 (Yang et al. 1997). Putative serine phosphorylation sites, as determined by phosphobase detection (http://www.cbs.dtu.dk/databases/PhosphoBase/predict/predict.html), are underlined. Ser ${ }^{424}$ is highlighted by an asterisk, indicating its strong likelihood as a protein kinase CK2 phosphorylation site.

HDAC3 is a direct substrate of $\mathrm{CK} 2$, we tested the ability of purified CK2 to phosphorylate HDAC3 in vitro. As shown in Figure 2, HDAC3 was readily phosphorylated by CK2 (Fig. 2B, left top panel, lane 1). Deletion analyses further showed that fragments containing the $\mathrm{C}$ terminus of HDAC3 (180-428, 266-428, 374-428), but not C-terminal truncation mutants $(1-265,1-180,1-122)$, are phosphorylated by CK2 (Fig. 2B, top panels, lanes $2-5,9,10)$. Significantly, an Ala substitution at $\mathrm{Ser}^{424}$ almost completely abolished the phosphorylation of HDAC3 by CK2, whereas the substitution of $\mathrm{Ser}^{405}$ with Ala had little effect (Fig. 2B, right top panel, lanes 7,8).

\section{Phosphorylation of HDAC3 on Ser ${ }^{424}$ alters its enzymatic activity}

Previous studies have suggested that the phosphorylation of HDAC1, HDAC2, or of HDAC8 affects their respective enzymatic activities (Pflum et al. 2001; Tsai and Seto 2002; Lee et al. 2004). To determine if the phosphorylation of $\mathrm{Ser}^{424}$ on HDAC3 influences its enzymatic activity, we expressed various Flag-HDAC3 mutants in HeLa cells and immunoprecipitated the proteins with anti-Flag antibodies to test their ability to deacetylate core histones. As shown in Figure 3A, the histone deacetylase activity of HDAC3 is strictly dependent on an intact $\mathrm{Ser}^{424}$ site. Mutation of Ser ${ }^{405}$, which is not appreciably phosphorylated by CK2, had no effect on deacetylase activity. In contrast, mutation of $\mathrm{Ser}^{424}$ alone or in combination with $\mathrm{Ser}^{405}$ severely reduces the enzymatic activity of HDAC3. Differences in the HDAC activity levels were not due to altered expression or subcellular localization, which were comparable between wild type and the S424A mutant (Fig. 3B, top panel, cf. lanes 1 and 3, lanes 2 and 4). These data thus suggest that the phosphorylation of $\mathrm{Ser}^{424}$ on HDAC3 by CK2 is absolutely critical for enzymatic activity.
Physical interaction between $P P 4_{C} / P P 4_{R 1}$ and HDAC3

Previously, we described the purification of an endogenous HDAC3 complex from total HeLa cell extracts using an anti-HDAC3 immuno-affinity column (Wen et al. 2000). We found that in addition to HDAC3, at least nine proteins (p215, p205, p195, p130, p125, p54, p52, p37, and p35) were specifically coeluted with HDAC activity. In gel tryptic digestion, followed by sequencing by microcapillary HPLC ion trap mass spectrometry, subsequently revealed that $\mathrm{p} 215, \mathrm{p} 205$, and $\mathrm{p} 195$ are derivatives of N-CoR and SMRT (Wen et al. 2000). In addition, p130 was identified as the transcription factor TFII-I (Tussie-Luna et al. 2002; Wen et al. 2003) and, consistent with other reports (Guenther et al. 2000; Li et al. 2000; Underhill et al. 2000; Zhang et al. 2002; Yoon et al. 2003), we elucidated that p54 and p52 are TBL1 and TBLR1, and that p37 is GPS2 (data not shown). To complete the identification of factors in the HDAC 3 complex in this study, we subjected the p125 protein to mass spectrometry analysis and found that this HDAC3-associated polypeptide is the $\mathrm{PP} 4_{\mathrm{R} 1}$ phosphatase (Fig. 4A).

To ensure that the copurification of $\mathrm{PP} 4_{\mathrm{R} 1}$ with HDAC3 was not a result of antibody cross-reactivity, we transfected HeLa cells with plasmids expressing Myc$\mathrm{PP}_{\mathrm{R} 1}$ and Flag-HDAC3 fusion proteins. Extracts prepared from transfected cells were then immunoprecipitated under low-stringency conditions with anti-Flag antibodies and immunoblotted with anti-Myc antibodies. As shown in Figure 4B (top panel), Myc-PP4 ${ }_{\mathrm{R} 1}$ coprecipitates with Flag-HDAC3 (lane 3) and this coprecipitated product was not seen in the absence of $\mathrm{Myc}_{\mathrm{PP}} 4_{\mathrm{R} 1}$, FlagHDAC3, or anti-Flag antibody (lanes 1,2,4).

To confirm our observation that HDAC 3 and $\mathrm{PP} 4_{\mathrm{R} 1}$ interact, we tested whether a GST-HDAC3 affinity matrix would capture PP4 ${ }_{\mathrm{R} 1}$ in vitro. Recombinant GSTHDAC3 (bacterially expressed) was bound to glutathi- 

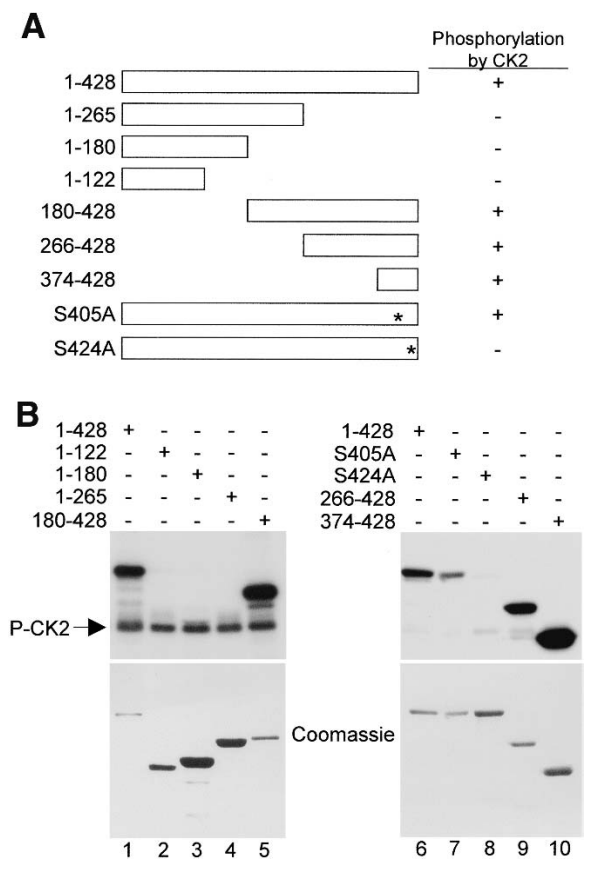

Figure 2. In vitro phosphorylation of HDAC3 by protein kinase CK2. (A) Schematic diagram of both full-length (1-428) and various truncated GST-HDAC3 proteins. Ser-to-Ala substitutions are denoted by asterisks, and the ability of each GSTHDAC3 protein to be phosphorylated by CK2 is indicated (+ or $-)$. For simplicity, the GST moieties of the fusion proteins are not shown. (B) Recombinant GST-HDAC proteins were incubated with purified CK2, followed by in vitro phosphorylation assay. (Top panels) Proteins were resolved by SDS-PAGE and ${ }^{32} \mathrm{P}$-radiolabeled proteins were visualized by autoradiography. To maximize resolution of different protein fragments, the two gels shown were prepared with two different percentages of polyacrylamide. Autophosphorylated CK2 products are indicated (left top panel), and Coomassie blue staining was performed prior to autoradiography for quantification purposes (bottom panels).

one-Sepharose beads and incubated with $\left[{ }^{35} S\right]$ methionine-labeled $\mathrm{PP} 4_{\mathrm{R} 1}$, produced by in vitro translation in a reticulocyte lysate. The beads were then washed and boiled in sample loading buffer, and the proteins were analyzed by electrophoresis in an SDS-polyacrylamide gel. PP $4_{\mathrm{R} 1}$ was found to be captured by the GST-HDAC3 fusion protein (Fig. 4C, lane 3), but not by the GST polypeptide alone (Fig. 4C, lane 2) or by GST-HDAC2 fusion protein (Fig. 4C, lane 4).

Our findings that endogenous $\mathrm{PP} 4_{\mathrm{R} 1}$ copurifies with endogenous HDAC 3 and that $\mathrm{PP} 4_{\mathrm{R} 1}$ interacts specifically with HDAC3 in two different assays prompted us to examine whether the $35-\mathrm{kDa}$ protein that copurified with HDAC3 could, in fact, be PP4 ${ }_{\mathrm{c}}$. A coprecipitation experiment was performed using 293T whole-cell extracts with anti-HDAC3 antibodies, followed by immunoblotting with anti-PP4 ${ }_{\mathrm{c}}$ antibodies. As shown in Figure $4 \mathrm{D}, \mathrm{PP}_{\mathrm{c}}$ coprecipitates with anti-HDAC3 (lane 3) but not with the preimmune sera (lane 2), anti-HDAC1 (lane 4), or anti-HDAC2 (lane 5), indicating that in addition to $\mathrm{PP} 4_{\mathrm{R} 1}, \mathrm{PP} 4_{\mathrm{c}}$ is present in the HDAC3 complex.
To confirm that $\mathrm{PP}_{\mathrm{c}}$, like $\mathrm{PP} 4_{\mathrm{R} 1}$, interacts specifically with HDAC3, we repeated our coprecipitation experiments shown in Figure 4B with HeLa cells expressing HA-PP4 $4_{\mathrm{c}}$. As predicted, HA-PP4 $4_{c}$ coprecipitates with Flag-HDAC3 only in the presence of both proteins and anti-Flag antibodies (Fig. 4E, top panel, lane 3). Significantly, HA-PP4 $4_{c}$ did not interact with either FlagHDAC1 or Flag-HDAC2 (Fig. 4F, top panel, lanes 2,3), indicating that the $\mathrm{HDAC} 3-\mathrm{PP} 4_{\mathrm{c}}$ association is highly specific.

The region incorporating residues 1-122 of HDAC3 is both necessary and sufficient for $\mathrm{HDAC} 3-\mathrm{PP}_{\mathrm{c}}$ interaction

To identify the domain(s) of HDAC3 that interacts with $\mathrm{PP}_{\mathrm{c}}$, we performed coprecipitation experiments with extracts of HeLa cells that were cotransfected with a plasmid expressing $\mathrm{HA}-\mathrm{PP} 4_{c}$ and plasmids expressing Flag fused to either full-length HDAC 3 or various deletion mutants of HDAC3. Our results indicate that the full-length HDAC3 (1-428) and the C-terminal deletion mutants (1-180 and 1-122) clearly bind PP4 ${ }_{c}$ (Fig. 5A,B [top panel, lanes 2-4]), whereas the $\mathrm{N}$-terminal deletion mutants of HDAC3 (122-428 and 180-428) do not bind PP4 ${ }_{c}$ (Fig. 5B, lanes 5,6). These data advocate that residues 122-428 of HDAC3 are not necessary for HDAC3-

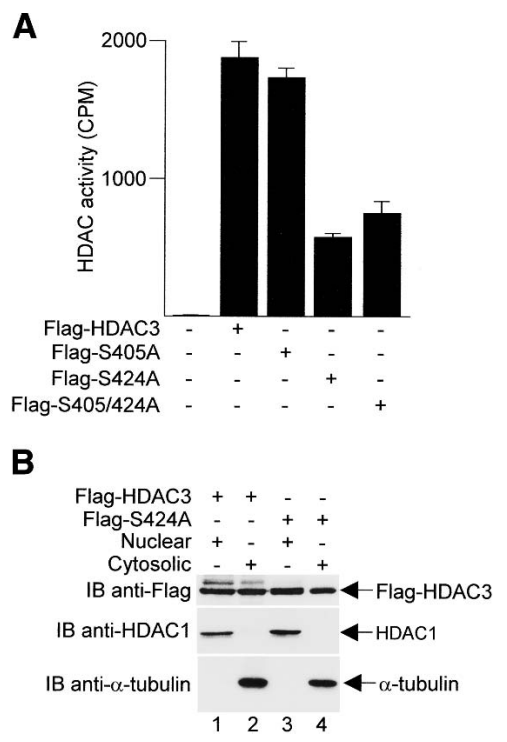

Figure 3. Mutation of $\mathrm{Ser}^{424}$ inhibits HDAC3 enzymatic activity. (A) HeLa cells were transfected with plasmids encoding either Flag-tagged wild-type or mutant HDAC3. Cell extracts were immunoprecipitated with anti-Flag antibodies and assayed for histone deacetylase (HDAC) activity. All transfections were normalized with parental expression vectors, and the data shown are the average results \pm SD from three separate experiments. ( $B$, top panel) Nuclear and cytosolic extracts were Western blotted with anti-Flag antibodies. The blot was then stripped and reprobed with either anti-HDAC1 (middle panel) or anti- $\alpha$-tubulin (bottom panel) antibodies to monitor the purity of nuclear and cytosolic fractions, respectively. 
A MADLSLLQEDLQEDADGSLDFVSQDEMLTPLGRLDKYAAS ENIFNROMVARSLLDTLREVCDDERDCIAVLERISRLADD SEPTVRAELMEQVPHIALFCOENRPS IPYAFSKFLLPIVV RYLADQNNOVRKTSQAALLALLEOELIERFDVETKVCPVL IFLTAPDSNDDVKTEAVAIMCKMAPMVGKDITERLILPRF CEMCCDCRMFHVRKVCAANFGDICSVVGQQATEEMLLPRF FQLCSDNVWGVRKACAECFMAVSCATCQEIRRTKLSALFI NLISDPSRWVRQAAFQSLGPF ISTFANPSSSGQYFKEESK SSEEMSVENKNRTRDQEAPEDVQVRPEDTPSDLSVSNSSV IT ENTMEDHAAFASGKPLGEISVPLDSSIICTISSESHO IT FWRTPLPEIDLDIELEONSGGKPSPEGPEEESEGPVPSSP FWRTPLPEIDLDIELEQNSGGKPSPEGPEEESEGPVPSSP SLDAHEETISIEKRSDLQDELDINELPNCKINQEDSVPLI SDAVENMDSTLHYIHSDSDLSNNSSF SPDEERRTKVODVV PQALLDQYLSMTDPSRAQTVDTEIAKHCAYSLPGVALTIG RONWHCLRETYETLASDMOWKVRRTLAF S I HELAVILGDO LTAADLVPIFNGFLKDLDEVRIGVLKHLHDFLKLLHIDKR REYLYQLQEFLVTDNSRNWRFRAELAEQIILLLELYSPRD VYDYLRPIALNLCADKVSSVRWISYKLVSEMVKKLHAATP PTFGVDLINELVENFGRCPKWSGRQAFVFVCQTVIEDDCI PMDQFAVHLMPHLLTLANDRVPNVRVLLAKTLROTLLEKD YFLASASCHOEAVEQTIMALOMDRDSDVKYFASIHPASTK ISEDAMSTASSTY

\section{c}

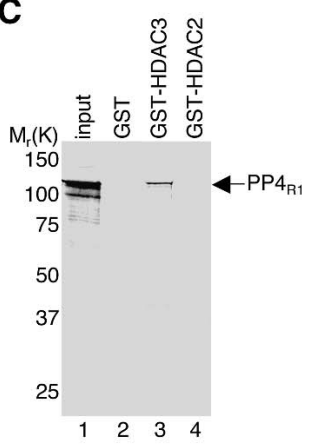

E

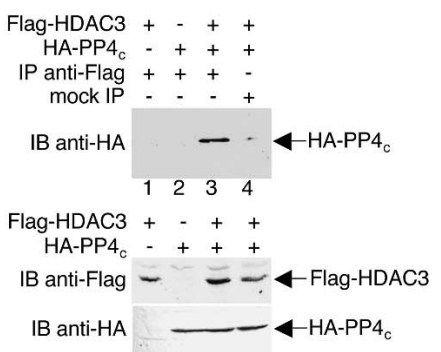

B
Flag-HDAC3 +-++

Myc-PP4 $_{\mathrm{R} 1}-+++$

IP anti-Flag +++

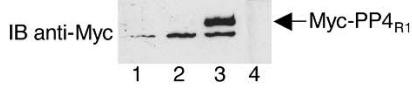

Flag-HDAC3 +-++

Myc-PP4 $_{\mathrm{R} 1}-+++$

IB anti-Flag — $\longrightarrow$ Flag-HDAC3

IB anti-Myc $\Longrightarrow-$ Myc-PP4 $_{\mathrm{R} 1}$ mock IP - - - +

Figure 4. HDAC3 physically associates with PP4. (A) Amino acid sequence of PP4 $4_{\mathrm{R} 1}$. The underlined peptide sequences were obtained by microcapillary reverse-phase HPLC nano-electrospray tandem mass spectrometry ( $\mu \mathrm{LC} / \mathrm{MS} / \mathrm{MS}$ ) on a Finnigan LCQ DECA XP Plus quadrupole ion trap mass spectrometer. $(B, E, F)$ Extracts prepared from HeLa cells transfected with plasmids encoding the indicated proteins were immunoprecipitated (IP) with anti-Flag antibodies and immunoblotted (IB) with either anti-Myc or antiHA antibodies. "Mock $\mathrm{IP}^{\prime}$ indicates reactions carried out identically but without anti-Flag antibodies. Direct immunoblots were performed on all extracts to assess protein expression levels. (C) GST-HDAC3 bound to glutathione-Sepharose beads was incubated with in vitro-translated, $\left[{ }^{35} \mathrm{~S}\right]$ methionine-labeled $\mathrm{PP} 4_{\mathrm{R} 1}$. Washed beads were boiled in sample buffer, and released proteins were electrophoresed on an SDS gel. Radiolabeled $\mathrm{PP} 4_{\mathrm{R} 1}$ was visualized by autoradiography. The input lane was loaded with $10 \%$ of the amount of ${ }^{35} \mathrm{~S}$-labeled protein used in the binding reactions. (D) $293 \mathrm{~T}$ whole-cell extracts were immunoprecipitated with anti-HDAC3, antiHDAC1, anti-HDAC2 antibodies, or preimmune sera (PIS). Precipitated material was Western blotted using anti-PP $4_{c}$ antibodies. The input lane was loaded with $1 \%$ of the amount of extract used in the immunoprecipitation reactions.
$\mathrm{PP} 4_{\mathrm{c}}$ associations and that the minimal interaction region is located within residues $1-122$.

\section{HDAC3 associates with protein phosphatase activity}

To determine whether the interaction with $\mathrm{PP} 4_{\mathrm{c}}$ causes the recruitment of phosphatase enzymatic activity by HDAC3, we expressed Flag-HDAC3 in HeLa cells, immunoprecipitated the tagged protein with anti-Flag antibodies, and assayed for phosphatase activity using a serine phosphopeptide and a nonradioactive malachite green phosphate detection solution. Negative controls included mock immunoprecipitations without anti-Flag or anti-Flag immunoprecipitations in extracts not expressing Flag-HDAC3. Interestingly, phosphatase activity coprecipitated with Flag-HDAC3 only in the presence of overexpressed PP4 ${ }_{c}$ but not $\mathrm{PP}_{\mathrm{R} 1}$ (Fig. 6A), sug- gesting that $\mathrm{PP}_{c}$ is the limiting component in the HDAC3-PP4 complex. Immunoprecipitations followed by Western blot analyses confirmed that HDAC3 is not normally saturated with $\mathrm{PP} 4_{\mathrm{c}}$, and the amount of interacting PP4 $4_{c}$ increases after overexpression (Fig. 6B).

\section{PP4 ${ }_{c}$ dephosphorylates HDAC3}

A conceivable functional consequence of the HDAC3$\mathrm{PP} 4$ interaction is that HDAC3 recruits $\mathrm{PP} 4$ to regulate the phosphorylation state of histones. Alternatively, though not mutually exclusive, is the possibility that HDAC3 serves as a substrate for $\mathrm{PP}_{\mathrm{c}}$. To test this possibility, HeLa cells were transfected with plasmids expressing Flag-HDAC3 and anti-Flag immunocomplexes were then immunoblotted with anti-phosphoserine antibodies. As shown in Figure 7A (upper left panel), 

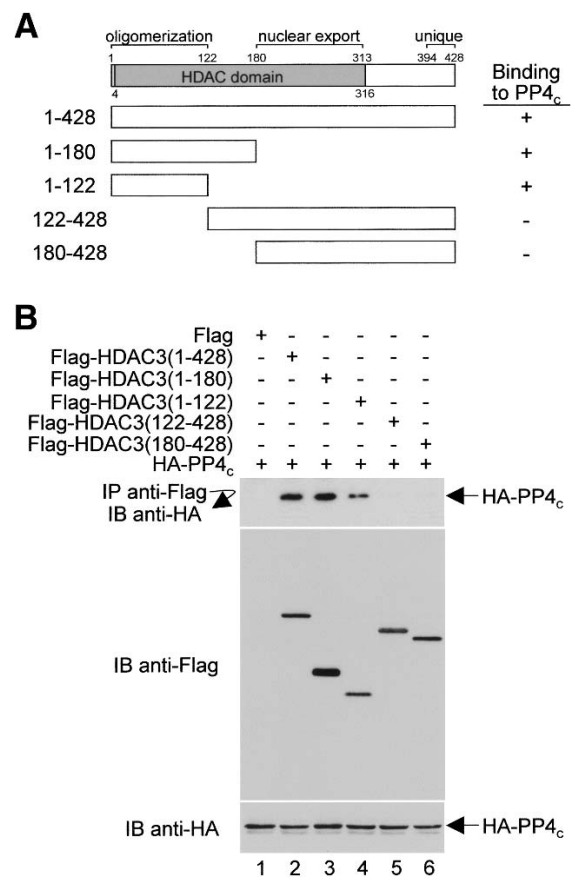

Figure 5. Mapping of the PP4 $4_{\mathrm{c}}$-interacting domain in HDAC3. (A) Schematic diagram of full-length (1-428) and various truncated Flag-HDAC3 fusion proteins. For simplicity, the Flag moieties are not shown. The ability of each Flag-HDAC3 fusion protein to bind HA-PP4 ${ }_{\mathrm{c}}$ is indicated (+ or -). (B) Anti-Flag immunoprecipitates (top panel) and total cellular extracts (middle and bottom panels) from transfected cells were immunoblotted (IB) with the indicated antibodies. Identical results were obtained from multiple experiments.

HDAC3 is serine phosphorylated in Flag-HDAC3-expressing cells (Fig. 7A, lane 2). Serine phosphorylation was markedly decreased in cells cotransfected with plasmids overexpressing PP4 ${ }_{c}$ either alone (Fig. 7A, lane 3) or with $\mathrm{PP}_{\mathrm{R} 1}$ (Fig. 7A, lane 5). Consistent with the fact that $\mathrm{PP}_{\mathrm{c}}$ interacts selectively with HDAC3, but not $\mathrm{HDAC} 1$ or HDAC2, the overexpression of $\mathrm{PP} 4_{c}$ was found to have no effect on serine phosphorylation of HDAC1 and HDAC2 (Fig. 7A, lanes 6-9).

To confirm that $\mathrm{PP}_{\mathrm{c}}$ dephosphorylates HDAC3 in vivo, HeLa cells expressing Flag-HDAC3 were treated with fostriecin, a potent PP4 inhibitor (Hastie and Cohen 1998; Boger et al. 2001; Lewy et al. 2002; Le et al. 2004), and anti-Flag immunocomplexes were again immunoblotted with anti-phosphoserine antibodies. As shown in Figure 7B (upper left panel), the level of serine phosphorylation in HDAC3 was much higher in fostriecintreated cells, compared to mock-treated cells (cf. lanes 2 and 3). The concentration of fostriecin (50 nM) used in these experiments does not affect the activities of PP1 or PP2B (Walsh et al. 1997; Cheng et al. 1998) and, as expected, treatment of cells with fostriecin had no effect on serine phosphorylation of HDAC2 (Fig. 7B, lanes 4,5).

\section{$P P 4_{c}$ down-regulates HDAC3 activity}

To determine whether dephosphorylation of HDAC3 by $\mathrm{PP}_{\mathrm{c}}$ modulates its deacetylase activity, HeLa cells were cotransfected with plasmids expressing Flag-HDAC3 and $\mathrm{PP} 4_{\mathrm{c}}$, and anti-Flag immune complexes were assayed for deacetylase activity using core histones as substrates. The presence of exogenous $\mathrm{PP} 4_{\mathrm{c}}$ greatly reduced the deacetylase activity of HDAC3 (Fig. 8A, left panel). We also compared the deacetylase activities of HDAC3 with the overexpression of $\mathrm{PP}_{\mathrm{R} 1}$ and found that, in agreement with the observation that overexpression of $\mathrm{PP}_{\mathrm{R} 1}$ alone does not affect the phosphorylation status of HDAC3, HDAC3 activity remained intact in the presence of overexpressed $\mathrm{PP} 4_{\mathrm{R} 1}$. In addition, consistent with our findings that $\mathrm{PP} 4_{c}$ had no effect on serine phosphorylation in HDAC1 and HDAC2, the overexpression of $\mathrm{PP} 4_{\mathrm{c}}$ had no effect on either HDAC1 or HDAC2 enzymatic activities (Fig. 8A, right panel).

To determine whether the effect of $\mathrm{PP} 4_{c}$ on HDAC3 activity is mediated through $\mathrm{Ser}^{424}$, we compared the effects of overexpressing $\mathrm{PP}_{\mathrm{c}}$ on S405A versus S424A mutants of HDAC3. As shown in Figure $8 \mathrm{~B}, \mathrm{PP} 4_{\mathrm{c}}$ re-

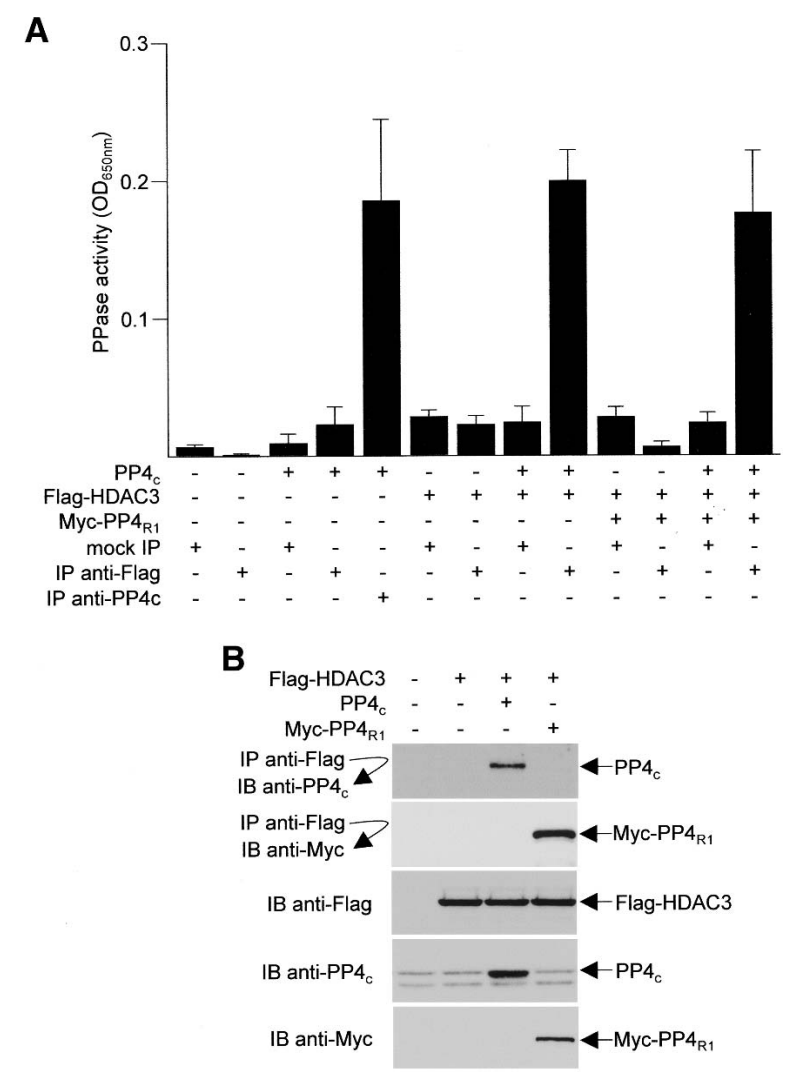

Figure 6. HDAC3-associated protein phosphatase activity. $(A)$ Serine phosphatase activities were assayed in anti-Flag immunoprecipitates of HeLa cells transfected with plasmids encoding $\mathrm{PP} 4_{\mathrm{c}}$, Flag-HDAC3, and/or Myc-PP4 ${ }_{\mathrm{R} 1}$. "Mock IP" indicates reactions carried out identically but without antibody. An anti$\mathrm{PP}_{\mathrm{c}}$ immunoprecipitate was used as a positive control. Each assay was performed in duplicate from three independent samples, and the values shown are the averages \pm SD. (B) Immunoprecipitates and total cellular extracts (inputs) from transfected cells were immunoblotted (IB) with the indicated antibodies to assess HDAC3-PP4 interactions and to control for protein expression. Representative blots are shown. 
A

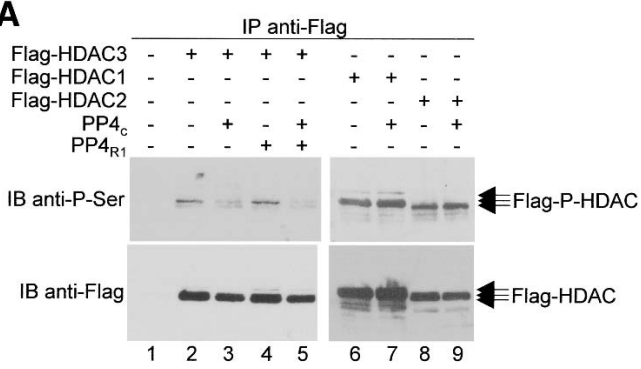

B

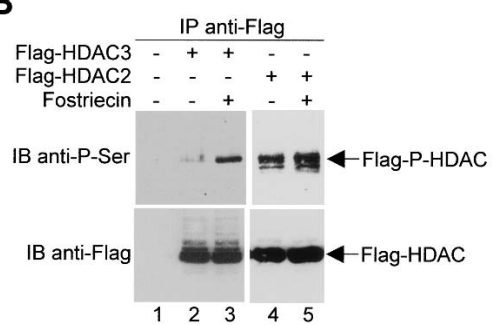

Figure 7. Regulation of HDAC3 phosphorylation by PP4. (A) HeLa cells were transfected with plasmids encoding FlagHDACs and PP4 as indicated. Extracts were then immunoprecipitated (IP) with anti-Flag antibodies and immunoblotted (IB) with anti-phosphoserine antibodies (top panels) or with antiFlag antibodies (bottom panels). (B) HeLa cells expressing either Flag-HDAC3 or Flag-HDAC2 were treated with $(+)$ or without (-) $50 \mathrm{nM}$ fostriecin. Cell extracts were immunoprecipitated and immunoblotted as in $A$.

duces the deacetylase activity of S405A (left panel). In contrast, $\mathrm{S} 424 \mathrm{~A}$, which is refractory to phosphorylation/ dephosphorylation, was not affected by the presence of PP4 $4_{c}$ (right panel), indicating that $\mathrm{PP} 4$ c acts by selectively dephosphorylating $\mathrm{Ser}^{424}$ to down-regulate HDAC3 activity.

To conclusively show that PP4 is, indeed, a negative regulator of HDAC3 activity, we immunoprecipitated Flag-HDAC3 from an extract prepared from HEK293 cells cotransfected with plasmids expressing FlagHDAC3 and PP4-RL, a dominant-negative PP4 mutant (Zhou et al. 2002). In subsequent HDAC activity assays, when compared to cells cotransfected with control vector, PP4-RL increased the activity of Flag-HDAC3 (Fig. 9A, left panel). This increase is highly specific, as the activity of Flag-HDAC1 was not altered by PP4-RL under identical conditions (Fig. 9A, right panel). In a tandem series of experiments, we examined HDAC3 activity in HeLa cells depleted of $\mathrm{PP}_{\mathrm{c}}$ by RNAi. A short hairpin RNA (shRNA) construct targeted against $\mathrm{PP}_{\mathrm{c}}$ (obtained from Open Biosystems) effectively reduced endogenous $\mathrm{PP}_{\mathrm{c}}$ (but not $\beta$-actin) levels and significantly increased the deacetylase activity of HDAC3 (Fig. 9B). These data firmly establish that an in vivo function of $\mathrm{PP}_{\mathrm{c}}$ is to down-modulate HDAC3 activity.

Previous immunoblotting and immunocytochemical studies using rat tissues have shown that the $\mathrm{PP} 4 \mathrm{c}$ protein is present in most tissues, with the highest levels of expression found in brain and testes (Kloeker et al. 1997).
We surveyed a large panel of human cell lines and repeatedly found that $\mathrm{PP}_{\mathrm{c}}$ is expressed at unusually low levels in HepG2 cells (Fig. 9C, top panel; data not shown). Based on this finding, we hypothesized that HDAC3 activity would be elevated in HepG2 cells as a result of the absence of $\mathrm{PP} 4_{\mathrm{c}}$. To test this theory, we transfected HepG2 cells with a plasmid that expresses Flag-HDAC3 and immunoprecipitated the exogenous protein with an anti-Flag antibody to assay for deacetylase activity. As shown in Figure 9C (bar graph), when compared to Flag-HDAC3 precipitated from HeLa cells, Flag-HDAC3 precipitated from HepG2 cells has much higher HDAC activity levels. Importantly, this robust HDAC3 activity extracted from HepG2 cells was reduced by overexpression of $\mathrm{PP}_{\mathrm{c}}$. Taken together, results from these experiments clearly demonstrate that the enzymatic activity of HDAC3 is heavily dependent on the cellular concentration of $\mathrm{PP}_{c}$.

\section{Discussion}

As would be expected for enzymes that control important cellular processes, the activities of HDACs are highly regulated (Legube and Trouche 2003; Sengupta and Seto 2004). In the case of HDAC3, a key mechanism underlying its positive regulation comes from its binding to the corepressors N-CoR/SMRT. In addition, similar to the well-characterized HDAC1 and HDAC2 proteins (Pflum et al. 2001; Tsai and Seto 2002), HDAC3 activity can be up-regulated via phosphorylation by protein kinase CK2. In this report we define a novel molecular mechanism for the negative regulation of HDAC3 activity by the protein phosphatase, PP4. We demonstrate that the enzymatic activity of HDAC3 is exquisitely sensitive to the cellular availability of PP4 ${ }_{\mathrm{c}}$.

Unlike HDAC1 and HDAC2, which are phosphorylated at multiple residues (Cai et al. 2001; Pflum et al. 2001; Tsai and Seto 2002), HDAC3 is primarily phosphorylated at its unique $\mathrm{Ser}^{424}$ site. This difference in their phosphorylation profiles suggests that distinct post-translational mechanisms regulate the activity of HDAC 3 and other class I HDACs. Previously, Galasinski et al. (2002) showed that treatment of cultured cells with the protein phosphatase inhibitor okadaic acid leads to hyperphosphorylation of HDAC1 and HDAC2, possibly through restraining the activity of PP1. In contrast to HDAC1 and HDAC2, however, HDAC3 both binds and acts as a substrate for PP4, but not PP1. We show that $\mathrm{PP}_{\mathrm{R} 1}$ and $\mathrm{PP} 4_{\mathrm{c}}$ copurify with endogenous HDAC3 and also bind HDAC3 in both coimmunoprecipitation and GST pull-down assays. Although $>60 \%$ identical in overall amino acid sequence, the sequence alignment comparisons of both the $\mathrm{N}$ and $\mathrm{C}$ termini of HDACs 1,2 , and 3 reveal substantial differences. The $\mathrm{N}$ terminus is required for oligomerization of HDAC3 (Yang et al. 2002) and also for cell viability (Takami and Nakayama 2000). The interaction of $\mathrm{PP}_{c}$ with the $\mathrm{N}$ terminus of HDAC3 fits well with the observation that $\mathrm{PP} 4{ }_{\mathrm{c}}$ partners with HDAC3, but not HDAC1 or HDAC2. In addition to $\mathrm{PP} 4_{\mathrm{c}}$, the $\mathrm{N}$ terminus of HDAC3 has also 
Zhang et al.

Figure 8. Negative regulation of HDAC3 activity by overexpression of $\mathrm{PP} 4_{\mathrm{c}} \cdot(A, B)$ HDAC activity was assayed in anti-Flag immunoprecipitates prepared from HeLa cells transfected with plasmids encoding different wild-type and mutant Flag-HDACs and PP4 as indicated. Immunoprecipitates or cell extracts were immunoblotted (IB) with different antibodies to monitor HDAC3-PP4 interactions and to normalize for protein expression (representative blots are shown). Each deacetylase assay was performed in duplicate from three independent samples, and the values shown are the averages \pm SD.
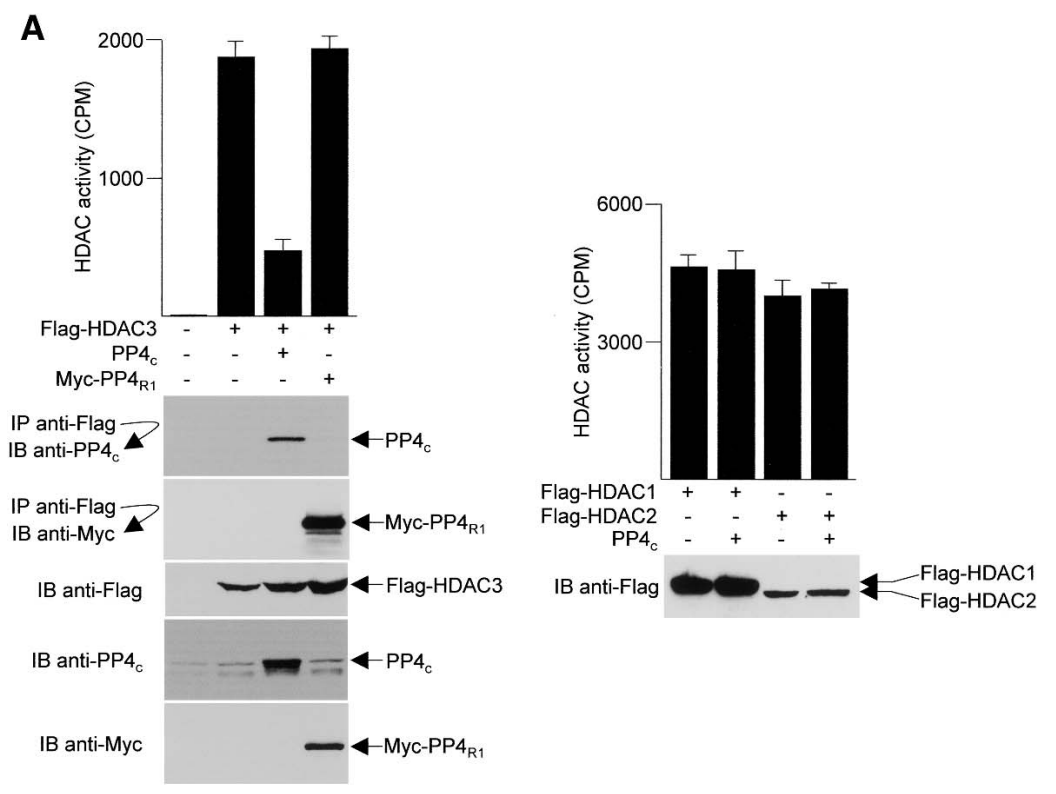

B
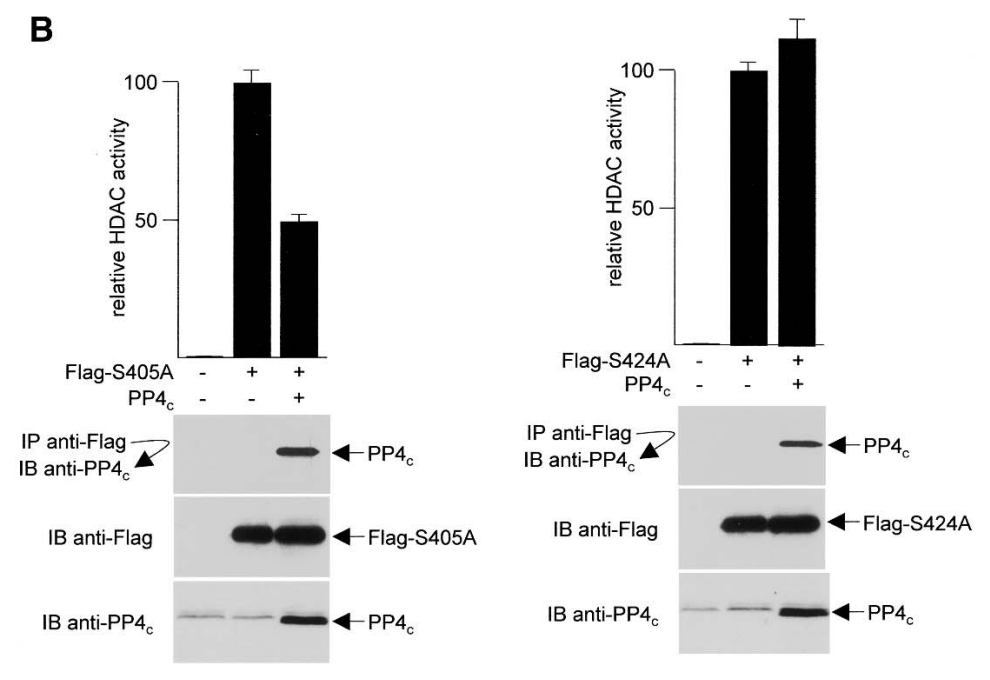

been previously shown to bind the orphan nuclear receptor TR2 (Li et al. 2003), RelA (Chen et al. 2001) and, most interestingly, the deacetylase-activating domain of SMRT (Guenther et al. 2001). Thus, it appears that this region of HDAC3 is a target of two opposing regulatory processes. It will, therefore, be important to examine whether the binding of $\mathrm{PP} 4_{c}$ and $\mathrm{N}-\mathrm{CoR} / \mathrm{SMRT}$ to HDAC3 is mutually exclusive, and if so, elucidate the conditions that determine which of these interactions is selected.

In an earlier study, we determined that the unique extreme C-terminal region of HDAC3, outside of the conserved HDAC domain, is important for deacetylase enzymatic activity (Yang et al. 2002). Our current results, showing that phosphorylation of $\mathrm{Ser}^{424}$ is critical for HDAC3 activity, are consistent with our previous findings showing that the deletion of the most C-terminal 27 residues of HDAC3 significantly lowers its activity, whereas Ala substitutions at $\mathrm{Pro}^{407}, \mathrm{Glu}^{412}, \mathrm{Asp}^{415}$,
$\mathrm{Asp}^{417}, \mathrm{Asp}^{421}$, and $\mathrm{Asp}^{425}$ have no effect on HDAC3 deacetylase activity (Yang et al. 2002).

An increasing body of evidence now suggests that many HDAC family members, including HDAC3, also deacetylate nonhistone proteins. Our finding that HDAC3 associates with PP4 raises the obvious question of whether $\mathrm{PP} 4_{\mathrm{R} 1}$ or $\mathrm{PP} 4_{\mathrm{c}}$ may be acetylated, and if so, whether these molecules could then serve as substrates for HDAC3. Another unexpected yet interesting finding of previous studies of HDACs is that, besides intrinsic deacetylase activity, some class I HDACs are tightly linked to additional histone and chromatin-modifying activities. For example, a large portion of HDAC1 and HDAC2 proteins have been shown to exist within the chromatin-remodeling NuRD/Mi2 complex in the cell (Tong et al. 1998; Wade et al. 1998; Zhang et al. 1998). HDAC1 and HDAC2 also interact with both DNA topoisomerase II and DNMT1 (Fuks et al. 2000; Robertson et al. 2000; Rountree et al. 2000; Tsai et al. 2000; Johnson 
A

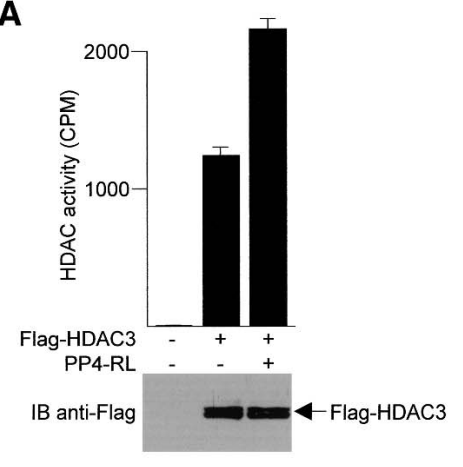

C
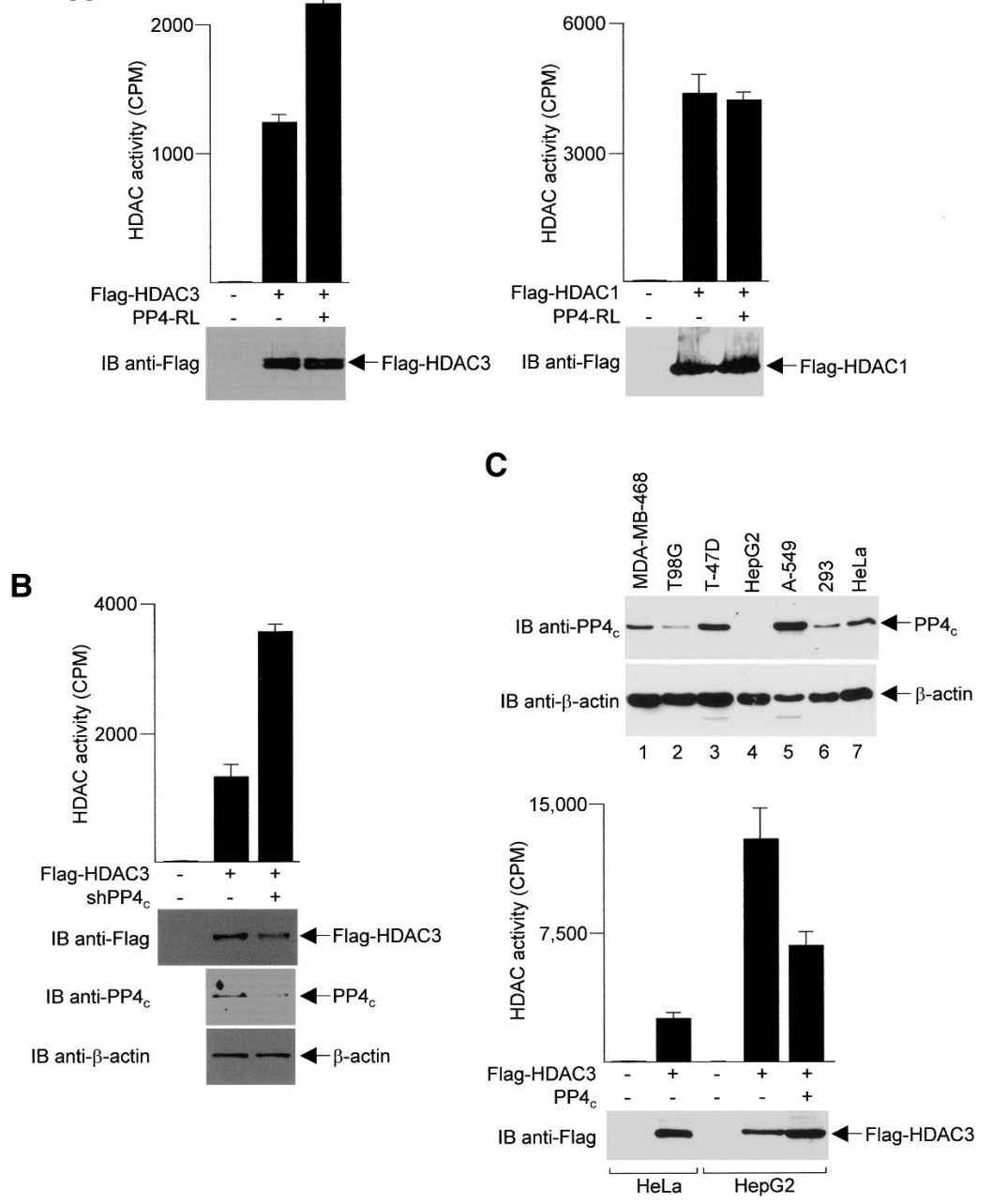

Figure 9. Up-regulation of HDAC3 activity by inhibition or depletion of $\mathrm{PP} 4_{\mathrm{c}}$. (A) HDAC activity was assayed in anti-Flag immunoprecipitates prepared from HEK293 cells transfected with plasmids encoding either Flag-HDAC3 (left panel) or Flag-HDAC1 (right panel) with PP4-RL as indicated. Immunoprecipitates were immunoblotted (IB) with anti-Flag antibodies to monitor FlagHDAC protein expression with and without PP4RL (representative blots are shown in bottom panels). Each assay was performed in duplicate from three independent samples, and the values shown are the averages \pm SD. $(B)$ Similar experiments were performed with shPP4 $4_{c}$ instead of PP4-RL, in HeLa cells. $(C$, top panel) Extracts of the indicated cell lines were immunoblotted with $\mathrm{PP} 4_{c}$ antibodies. The blots were stripped and reprobed with an anti- $\beta$-actin antibody to normalize for protein loading and transfer. HepG2 and HeLa cells were transfected with a plasmid encoding Flag-HDAC3. (Bottom panel) Flag immunoprecipitates were assayed for deacetylase activity or immunoblotted with anti-Flag antibodies. et al. 2001). In addition, a protein previously found in several different HDAC1/2-containing complexes was recently identified as a histone demethylase (Shi et al. 2004). It has been suggested that some HDACs may facilitate chromatin modification by targeting additional enzymes to chromatin regions that are actively undergoing histone deacetylation. Our finding that PP4 binds HDAC3 unveils the unprecedented possibility that an HDAC might recruit a phosphatase to dephosphorylate histones. Our data showing that HDAC3 immune complexes possess phosphatase activity enhance the attractiveness and feasibility of this model. Further studies are now under way in our laboratory to determine whether PP4 functions as a histone phosphatase.

An important question that remains is how the dephosphorylation of $\mathrm{Ser}^{424}$ on HDAC3 negatively regulates HDAC3 activity. Thus far, we have ruled out the possibility that dephosphorylation of HDAC3 changes the subcellular localization of HDAC3. An alternative possibility is that dephosphorylation of HDAC3 by PP4 causes a conformational change that renders it less active. Another equally plausible scenario is that the dephosphorylation of HDAC3 by PP4 affects its ability to interact with other proteins. Coimmunoprecipitation experiments did not detect any difference in the ability of phosphorylated versus nonphosphorylated HDAC3 to associate with N-CoR (data not shown), but further experiments designed to identify proteins that might selectively interact with phosphorylated HDAC3 are now under way.

As mentioned previously, the biological functions of PP4 are not well understood. Although predominately nuclear (Kloeker et al. 1997), some PP4 $4_{\mathrm{c}}$ is present in cytoplasm and, more interestingly, in mitotic centrosomes in both human and Drosophila cells. This cellular distribution pattern suggests that PP4 possesses diverse functions, including the regulation of nucleation and stabilization of microtubules (Brewis et al. 1993). Indeed, Drosophila embryos with subnormal amounts of $\mathrm{PP} 4_{\mathrm{c}}$ are unable to complete mitosis due to a lack of microtubules (Helps et al. 1998), and it has been shown that Caenorhabditis elegans requires PP4 for centrosome maturation in mitosis and sperm meiosis (Sumiyoshi et al. 2002). At the present time, we do not know whether dephosphorylation of HDAC3 by PP4, and the consequent decrease in HDAC activity, contributes to the role of PP4 in mitosis. However, we favor the idea that the biological consequence of HDAC3 dephosphorylation by 
PP4 is unrelated to either microtubule stabilization or cell division for two reasons. First, HDAC3 colocalizes with $\mathrm{PP} 4_{\mathrm{R} 1}$ and $\mathrm{PP} 4_{\mathrm{c}}$ outside of the centrosomes (data not shown). Second, in contrast to $\mathrm{PP} 4_{\mathrm{R} 1}$, the $50-\mathrm{kDa}$ $\mathrm{PP}_{\mathrm{R} 2}$ subunit, which targets $\mathrm{PP} 4_{\mathrm{c}}$ to centrosomes (Hastie et al. 2000), does not copurify with HDAC3.

In addition to HDAC3, PP4 might be involved in the regulation of NF- $\mathrm{KB}$ p $65 \mathrm{Thr}$ phosphorylation (Hu et al. 1998). In doing so, it has been suggested that PP4 presumably activates NF- $\mathrm{BB}$ and facilitates TNF $\alpha$-induced activation of JNK kinase (Zhou et al. 2002; Mihindukulasuriya et al. 2004; Yeh et al. 2004; Zhou et al. 2004). Since HDAC3 is a regulator of NF- $\mathrm{KB}$ and of the JNK pathway (Chen et al. 2001; Zhang et al. 2002; Weiss et al. 2003), it will be important to elucidate the association of HDAC3 dephosphorylation by PP4 with these signaling pathways in future studies. Finally, it has been shown that PP4 may have a proapoptotic role in T-lymphocytes (Mourtada-Maarabouni et al. 2003). Because previous studies suggest that the survival of normal cells requires HDAC3 (Dangond et al. 1998, 1999; Glaser et al. 2003), the possibility that HDAC3 could be a mediator of the proapoptotic effect by PP4 also warrants further investigation.

\section{Materials and methods}

\section{Plasmids}

Mammalian expression plasmids for Flag-HDAC3 (Yang et al. 1997; Wen et al. 2000), Flag-HDAC3 deletion mutants (Yang et al. 2002), Flag-HDAC1 (Taunton et al. 1996), Flag-HDAC2 (Laherty et al. 1997), Myc-PP4 ${ }_{\mathrm{R} 1}$ (Kloeker and Wadzinski 1999), HA-PP4 (Hu et al. 1998), and PP4-RL (Zhou et al. 2002) have been previously described. Expression plasmids for nontagged $\mathrm{PP} 4_{\mathrm{c}}$ and $\mathrm{PP} 4_{\mathrm{R} 1}$ were constructed by standard PCR and subcloned into the pcDNA3.1(+) vector (Invitrogen). Bacterial expression plasmids for GST-HDAC2 and GST-HDAC3 have also been previously described (Yang et al. 1997), and the various GST-HDAC3 deletion plasmids were generated by PCR and subcloned into the pGEX4T-1 vector (Pharmacia). Flag-S405A, Flag-S424A, and Flag-S405A/S424A expression plasmids were derived from pFlag-HDAC3 with the Quick-change site-directed mutagenesis kit (Stratagene). Likewise, bacterial expression plasmids for GST-S405A and GST-S424A were generated from pGEX-HDAC3 using identical strategies. All constructs were verified by DNA sequencing.

\section{Cell culture and transfection}

Cells were maintained in Dulbecco's modified Eagle's medium (DMEM) supplemented with $10 \%$ fetal bovine serum. Transfections were performed with Lipofectamine 2000 (Invitrogen) according to the manufacturer's instruction. Cells were harvested $48 \mathrm{~h}$ after transfection for further analysis.

\section{In vivo phosphate labeling and phosphoamino acid analysis}

HeLa cells transfected with the Flag vector or with Flag-HDAC3 expression plasmids were preincubated with phosphate-free DMEM for $1 \mathrm{~h}$ before labeling. Cells were then treated with ${ }^{32} \mathrm{P}$-orthophosphate at a concentration of $0.5 \mathrm{mCi} / \mathrm{mL}$ for $4 \mathrm{~h}$ at $37^{\circ} \mathrm{C}$ and lysed in a modified RIPA buffer. Flag-tagged proteins were immunoprecipitated with Flag M2 agarose under highstringency conditions and resolved by $8 \%$ SDS-PAGE. Phosphorylated proteins were detected by autoradiography. For phosphoamino acid analysis, ${ }^{32} \mathrm{P}$-labeled Flag-HDAC3 was transferred onto a polyvinylidene difluoride (PVDF) membrane, and the membrane was exposed to X-ray film. The HDAC3specific band was excised and hydrolyzed in $6 \mathrm{~N} \mathrm{HCl}$ for $1 \mathrm{~h}$ at $110^{\circ} \mathrm{C}$. The hydrolysate was separated by two-dimensional electrophoresis on thin-layer cellulose with the HTLE-7000 system as described previously (Blume-Jensen and Hunter 2001).

\section{Immunoprecipitation and immunoblotting analysis}

Anti-Flag, anti-HA, anti- $\alpha$-tubulin, and anti- $\beta$-actin antibodies were purchased from Sigma-Aldrich; anti-Myc and anti-PP4 ${ }_{c}$ antibodies were purchased from Santa Cruz Biotechnology; antiphosphoserine antibody was purchased from Zymed Laboratories. Rabbit polyclonal anti-HDAC1, anti-HDAC2, and antiHDAC3 antibodies were produced as described previously (Taunton et al. 1996; Laherty et al. 1997; Wen et al. 2000). For immunoprecipitations, cells were rinsed with ice-cold PBS and lysed in $1 \mathrm{~mL}$ of either high-stringency buffer (a modified RIPA buffer containing $20 \mathrm{mM}$ Tris- $\mathrm{HCl}$ at $\mathrm{pH} 7.4,150 \mathrm{mM} \mathrm{NaCl}, 2$ mM EDTA, $1 \%$ NP-40, and a cocktail of protease inhibitors) or low-stringency buffer (PBS containing 0.1\% NP-40, 10\% glycerol, and a cocktail of protease inhibitors). The lysates were immunoprecipitated with the primary antibody overnight at $4^{\circ} \mathrm{C}$, and the immunocomplexes were collected, washed four times, and resolved by SDS-PAGE. For immunoblotting, samples were transferred onto nitrocellulose membranes. Membranes were probed with the appropriate antibodies, and proteins recognized by the antibodies were detected using the Chemiluminescent Detection Kit (Pierce). In some experiments, conventional horseradish peroxidase conjugated anti-rabbit IgG blotting reagents were substituted with Rabbit IgG TrueBlot (eBioscience) to eliminate interference of signal detection by the immunoglobulin heavy and light chains.

\section{In vitro kinase assay}

GST-fusion proteins were incubated with $500 \mathrm{U}$ of recombinant CK2 (New England Biolab) in the presence of $5 \mu \mathrm{Ci}$ of $\left[\gamma^{-32} \mathrm{P}\right] \mathrm{ATP}, 100 \mu \mathrm{M}$ ATP, and manufacturer-supplied kinase buffers in a total volume of $20 \mu \mathrm{L}$ for $30 \mathrm{~min}$ at $30^{\circ} \mathrm{C}$. The reactions were terminated by addition of $2 \times$ SDS sample loading buffer and boiled for $5 \mathrm{~min}$. After electrophoresis, gels were stained with Coomassie blue and dried, and phosphorylated products were visualized by autoradiography.

\section{GST pull-down assay}

GST, GST-HDAC3, and GST-HDAC2 were expressed and purified as previously described (Yang et al. 1997). ${ }^{35} \mathrm{~S}-\mathrm{PP} 4_{\mathrm{R} 1}$ was prepared using the coupled transcription-translation rabbit reticulocyte lysate system (Promega). Equimolar quantities of GST, GST-HDAC3, or GST-HDAC2 conjugated to glutathioneSepharose beads were incubated with radiolabeled PP4 $4_{\mathrm{R} 1}$. Binding reactions, washing conditions, electrophoretic analysis, and subsequent autoradiography were performed as previously described (Yang et al. 1997).

\section{Phosphatase assay}

Phosphatase assays were performed using the Ser/Thr Phosphatase Assay Kit 1 (Upstate Biotechnology) according to the manufacturer's instructions. Immunoprecipitates (free of phosphate) 
were incubated with $4 \mu \mathrm{M}$ RRApSVA peptide in $30 \mu \mathrm{L}$ of assay buffer $\left(50 \mathrm{mM}\right.$ Tris at $\left.\mathrm{pH} 7.0,0.1 \mathrm{mM} \mathrm{CaCl}_{2}\right)$ at $30^{\circ} \mathrm{C}$ for $30 \mathrm{~min}$. Enzyme reactions were terminated by the addition of $100 \mu \mathrm{L}$ of Malachite Green solution. After 15 min of color development at room temperature, phosphatase activities were determined by measuring the absorbance at $650 \mathrm{~nm}$.

\section{Histone deacetylase assay}

Deacetylase activity was determined using hyperacetylated core histones purified from HeLa cells. Briefly, immunoprecipitated samples were incubated with $\left[{ }^{3} \mathrm{H}\right]$ acetate-labeled core histones in $150 \mu \mathrm{L}$ of reaction buffer $(20 \mathrm{mM}$ Tris at $\mathrm{pH} 8.0,150$ $\mathrm{mM} \mathrm{NaCl}$, and $10 \%$ glycerol) at room temperature overnight. Reactions were quenched with $1 \mathrm{M} \mathrm{HCl}$ and $0.16 \mathrm{M}$ acetic acid (50 $\mu \mathrm{L}$ in each sample). Released $\left[{ }^{3} \mathrm{H}\right]$ acetic acid was extracted with $600 \mu \mathrm{L}$ of ethyl acetate by vortexing and centrifugation $(5$ min at $14,000 \mathrm{rpm})$. Ethyl acetate supernatants $(300 \mu \mathrm{L}$ from each sample) were quantified by scintillation counting.

\section{Acknowledgments}

We thank Bill Lane and his colleagues at the Harvard Microsequencing Facility for their assistance with protein microsequencing, Ryan Seto for technical assistance, Nancy Olashaw and Michele Glozak for discussion and critical reading of the manuscript, and the Moffitt Cancer Center Core Facility for their specialized support. This work was supported by grants to E.S. from the NIH (GM58486, CA109699) and the Kaul Foundation.

\section{References}

Amann, J.M., Nip, J., Strom, D.K., Lutterbach, B., Harada, H., Lenny, N., Downing, J.R., Meyers, S., and Hiebert, S.W. 2001. ETO, a target of $\mathrm{t}(8 ; 21)$ in acute leukemia, makes distinct contacts with multiple histone deacetylases and binds $\mathrm{mSin} 3 \mathrm{~A}$ through its oligomerization domain. Mol. Cell. Biol. 21: 6470-6483.

Blom, N., Gammeltoft, S., and Brunak, S. 1999. Sequence and structure-based prediction of eukaryotic protein phosphorylation sites. J. Mol. Biol. 294: 1351-1362.

Blume-Jensen, P. and Hunter, T. 2001. Two-dimensional phosphoamino acid analysis. Methods Mol. Biol. 124: 49-65.

Boger, D.L., Ichikawa, S., and Zhong, W. 2001. Total synthesis of fostriecin (CI-920). J. Am. Chem. Soc. 123: 4161-4167.

Brehm, A., Miska, E.A., McCance, D.J., Reid, J.L., Bannister, A.J., and Kouzarides, T. 1998. Retinoblastoma protein recruits histone deacetylase to repress transcription. Nature 391: 597-601.

Brewis, N.D., Street, A.J., Prescott, A.R., and Cohen, P.T. 1993. PPX, a novel protein serine/threonine phosphatase localized to centrosomes. EMBO J. 12: 987-996.

Cai, R., Kwon, P., Yan-Neale, Y., Sambuccetti, L., Fischer, D., and Cohen, D. 2001. Mammalian histone deacetylase 1 protein is posttranslationally modified by phosphorylation. Biochem. Biophys. Res. Commun. 283: 445-453.

Chen, L., Fischle, W., Verdin, E., and Greene, W.C. 2001. Duration of nuclear NF- $\mathrm{B}$ action regulated by reversible acetylation. Science 293: 1653-1657.

Cheng, A., Balczon, R., Zuo, Z., Koons, J.S., Walsh, A.H., and Honkanen, R.E. 1998. Fostriecin-mediated G2-M-phase growth arrest correlates with abnormal centrosome replication, the formation of aberrant mitotic spindles, and the inhibition of serine/threonine protein phosphatase activity.
Cancer Res. 58: 3611-3619.

Dangond, F., Hafler, D.A., Tong, J.K., Randall, J., Kojima, R., Utku, N., and Gullans, S.R. 1998. Differential display cloning of a novel human histone deacetylase (HDAC3) cDNA from PHA-activated immune cells. Biochem. Biophys. Res. Commun. 242: 648-652.

Dangond, F., Foerznler, D., Weremowicz, S., Morton, C.C., Beier, D.R., and Gullans, S.R. 1999. Cloning and expression of a murine histone deacetylase 3 (mHdac3) cDNA and mapping to a region of conserved synteny between murine chromosome 18 and human chromosome 5. Mol. Cell. Biol. Res. Commun. 2: 91-96.

Durst, K.L., Lutterbach, B., Kummalue, T., Friedman, A.D., and Hiebert, S.W. 2003. The inv(16) fusion protein associates with corepressors via a smooth muscle myosin heavy-chain domain. Mol. Cell. Biol. 23: 607-619.

Emiliani, S., Fischle, W., Van, L.C., Al, A.Y., and Verdin, E. 1998. Characterization of a human RPD3 ortholog, HDAC3. Proc. Nat1. Acad. Sci. 95: 2795-2800.

Fuks, F., Burgers, W.A., Brehm, A., Hughes-Davies, L., and Kouzarides, T. 2000. DNA methyltransferase Dnmt1 associates with histone deacetylase activity. Nat. Genet. 24: 8891.

Galasinski, S.C., Resing, K.A., Goodrich, J.A., and Ahn, N.G. 2002. Phosphatase inhibition leads to histone deacetylases 1 and 2 phosphorylation and disruption of corepressor interactions. J. Biol. Chem. 277: 19618-19626.

Gelmetti, V., Zhang, J., Fanelli, M., Minucci, S., Pelicci, P.G., and Lazar, M.A. 1998. Aberrant recruitment of the nuclear receptor corepressor-histone deacetylase complex by the acute myeloid leukemia fusion partner ETO. Mol. Cell. Biol. 18: 7185-7191.

Glaser, K.B., Li, J., Staver, M.J., Wei, R.Q., Albert, D.H., and Davidsen, S.K. 2003. Role of class I and class II histone deacetylases in carcinoma cells using siRNA. Biochem. Biophys. Res. Commun. 310: 529-536.

Grignani, F., De Matteis, S., Nervi, C., Tomassoni, L., Gelmetti, V., Cioce, M., Fanelli, M., Ruthardt, M., Ferrara, F.F., Zamir, I., et al. 1998. Fusion proteins of the retinoic acid receptor- $\alpha$ recruit histone deacetylase in promyelocytic leukaemia. $\mathrm{Na}$ ture 391: 815-818.

Guenther, M.G., Lane, W.S., Fischle, W., Verdin, E., Lazar, M.A., and Shiekhattar, R. 2000. A core SMRT corepressor complex containing HDAC3 and TBL1, a WD40-repeat protein linked to deafness. Genes \& Dev. 14: 1048-1057.

Guenther, M.G., Barak, O., and Lazar, M.A. 2001. The SMRT and $\mathrm{N}-\mathrm{CoR}$ corepressors are activating cofactors for histone deacetylase 3. Mol. Cell. Biol. 21: 6091-6101.

Guenther, M.G., Yu, J., Kao, G.D., Yen, T.J., and Lazar, M.A. 2002. Assembly of the SMRT-histone deacetylase 3 repression complex requires the TCP-1 ring complex. Genes \& Dev. 16: 3130-3135.

Guidez, F., Petrie, K., Ford, A.M., Lu, H., Bennett, C.A., MacGregor, A., Hannemann, J., Ito, Y., Ghysdael, J., Greaves, M., et al. 2000. Recruitment of the nuclear receptor corepressor N-CoR by the TEL moiety of the childhood leukemia-associated TEL-AML1 oncoprotein. Blood 96: 2557-2561.

Hastie, C.J. and Cohen, P.T. 1998. Purification of protein phosphatase 4 catalytic subunit: Inhibition by the antitumour drug fostriecin and other tumour suppressors and promoters. FEBS Lett. 431: 357-361.

Hastie, C.J., Carnegie, G.K., Morrice, N., and Cohen, P.T. 2000. A novel $50 \mathrm{kDa}$ protein forms complexes with protein phosphatase 4 and is located at centrosomal microtubule organizing centres. Biochem. J. 347: 845-855.

Helps, N.R., Brewis, N.D., Lineruth, K., Davis, T., Kaiser, K., 
and Cohen, P.T. 1998. Protein phosphatase 4 is an essential enzyme required for organisation of microtubules at centrosomes in Drosophila embryos. J. Cell Sci. 111: 1331-1340.

Hu, M.C., Tang-Oxley, Q., Qiu, W.R., Wang, Y.P., Mihindukulasuriya, K.A., Afshar, R., and Tan, T.H. 1998. Protein phosphatase $\mathrm{X}$ interacts with c-Rel and stimulates c-Rel/nuclear factor $\kappa$ B activity. J. Biol. Chem. 273: 33561-33565.

Huang, X., Cheng, A., and Honkanen, R.E. 1997. Genomic organization of the human PP4 gene encoding a serine/threonine protein phosphatase (PP4) suggests a common ancestry with PP2A. Genomics 44: 336-343.

Ishizuka, T. and Lazar, M.A. 2003. The N-CoR/histone deacetylase 3 complex is required for repression by thyroid hormone receptor. Mol. Cell. Biol. 23: 5122-5131.

Jepsen, K. and Rosenfeld, M.G. 2002. Biological roles and mechanistic actions of co-repressor complexes. J. Cell Sci. 115: 689-698.

Johnson, C.A., Barlow, A.L., and Turner, B.M. 1998. Molecular cloning of Drosophila melanogaster cDNAs that encode a novel histone deacetylase dHDAC3. Gene 221: 127-134.

Johnson, C.A., Padget, K., Austin, C.A., and Turner, B.M. 2001. Deacetylase activity associates with topoisomerase II and is necessary for etoposide-induced apoptosis. J. Biol. Chem. 276: 4539-4542.

Juan, L.J., Shia, W.J., Chen, M.H., Yang, W.M., Seto, E., Lin, Y.S., and $\mathrm{Wu}, \mathrm{C} . \mathrm{W} .2000$. Histone deacetylases specifically downregulate p53-dependent gene activation. I. Biol. Chem. 275: 20436-20443.

Kelly, W.K., O'Connor, O.A., and Marks, P.A. 2002. Histone deacetylase inhibitors: From target to clinical trials. Expert Opin. Investig. Drugs 11: 1695-1713.

Kloeker, S. and Wadzinski, B.E. 1999. Purification and identification of a novel subunit of protein serine/threonine phosphatase 4. J. Biol. Chem. 274: 5339-5347.

Kloeker, S., Bryant, J.C., Strack, S., Colbran, R.J., and Wadzinski, B.E. 1997. Carboxymethylation of nuclear protein serine/threonine phosphatase X. Biochem. J. 327: 481-486.

Laherty, C.D., Yang, W.M., Sun, J.M., Davie, J.R., Seto, E., and Eisenman, R.N. 1997. Histone deacetylases associated with the $\mathrm{mSin} 3$ corepressor mediate mad transcriptional repression. Cell 89: 349-356.

Le, L.H., Erlichman, C., Pillon, L., Thiessen, J.J., Day, A., Wainman, N., Eisenhauer, E.A., and Moore, M.J. 2004. Phase I and pharmacokinetic study of fostriecin given as an intravenous bolus daily for five consecutive days. Invest. New Drugs 22: 159-167.

Lee, H., Rezai-Zadeh, N., and Seto, E. 2004. Negative regulation of histone deacetylase 8 activity by cyclic AMP-dependent protein kinase A. Mol. Cell. Biol. 24: 765-773.

Legube, G. and Trouche, D. 2003. Regulating histone acetyltransferases and deacetylases. EMBO Rep. 4: 944-947.

Lewy, D.S., Gauss, C.M., Soenen, D.R., and Boger, D.L. 2002. Fostriecin: Chemistry and biology. Curr. Med. Chem. 9: 2005-2032.

Li, J., Wang, J., Nawaz, Z., Liu, J.M., Qin, J., and Wong, J. 2000. Both corepressor proteins SMRT and N-CoR exist in large protein complexes containing HDAC3. EMBO J. 19: 43424350.

Li, G., Franco, P.J., and Wei, L.N. 2003. Identification of histone deacetylase- 3 domains that interact with the orphan nuclear receptor TR2. Biochem. Biophys. Res. Commun. 310: 384390.

Lin, R.J., Nagy, L., Inoue, S., Shao, W., Miller Jr., W.H., and Evans, R.M. 1998. Role of the histone deacetylase complex in acute promyelocytic leukaemia. Nature 391: 811-814.

Lu, X. and Horvitz, H.R. 1998. lin-35 and lin-53, two genes that antagonize a C. elegans Ras pathway, encode proteins similar to $\mathrm{Rb}$ and its binding protein RbAp48. Cell 95: 981-991.

Luo, J., Su, F., Chen, D., Shiloh, A., and Gu, W. 2000. Deacetylation of p53 modulates its effect on cell growth and apoptosis. Nature 408: 377-381.

Luo, J., Nikolaev, A.Y., Imai, S., Chen, D., Su, F., Shiloh, A., Guarente, L., and Gu, W. 2001. Negative control of p53 by Sir2 $\alpha$ promotes cell survival under stress. Cell 107: 137-148.

Lutterbach, B., Westendorf, J.J., Linggi, B., Patten, A., Moniwa, M., Davie, J.R., Huynh, K.D., Bardwell, V.J., Lavinsky, R.M., Rosenfeld, M.G., et al. 1998. ETO, a target of $t(8 ; 21)$ in acute leukemia, interacts with the N-CoR and $\mathrm{mSin} 3$ corepressors. Mol. Cell. Biol. 18: 7176-7184.

Magnaghi-Jaulin, L., Groisman, R., Naguibneva, I., Robin, P., Lorain, S., Le Villain, J.P., Troalen, F., Trouche, D., and Harel-Bellan, A. 1998. Retinoblastoma protein represses transcription by recruiting a histone deacetylase. Nature 391: 601-605.

Mahlknecht, U., Hoelzer, D., Bucala, R., and Verdin, E. 1999. Cloning and characterization of the murine histone deacetylase (HDAC3). Biochem. Biophys. Res. Commun. 263: 482490.

Marks, P.A., Rifkind, R.A., Richon, V.M., Breslow, R., Miller, T., and Kelly, W.K. 2001. Histone deacetylases and cancer: Causes and therapies. Nat. Rev. Cancer 1: 194-202.

Marks, P.A., Miller, T., and Richon, V.M. 2003. Histone deacetylases. Curr. Opin. Pharmacol. 3: 344-351.

Marks, P.A., Richon, V.M., Kelly, W.K., Chiao, J.H., and Miller, T. 2004. Histone deacetylase inhibitors: Development as cancer therapy. Novartis Found. Symp. 259: 269-281.

Mihindukulasuriya, K.A., Zhou, G., Qin, J., and Tan, T.H. 2004. Protein Phosphatase 4 interacts with and down-regulates insulin receptor substrate 4 following tumor necrosis factor- $\alpha$ stimulation. J. Biol. Chem. 279: 46588-46594.

Mourtada-Maarabouni, M., Kirkham, L., Jenkins, B., Rayner, J., Gonda, T.J., Starr, R., Trayner, I., Farzaneh, F., and Williams, G.T. 2003. Functional expression cloning reveals proapoptotic role for protein phosphatase 4. Cell Death Differ. 10: $1016-1024$.

Pflum, M.K., Tong, J.K., Lane, W.S., and Schreiber, S.L. 2001. Histone deacetylase 1 phosphorylation promotes enzymatic activity and complex formation. J. Biol. Chem. 276: 4773347741.

Robertson, K.D., Ait-Si-Ali, S., Yokochi, T., Wade, P.A., Jones, P.L., and Wolffe, A.P. 2000. DNMT1 forms a complex with $\mathrm{Rb}, \mathrm{E} 2 \mathrm{~F} 1$ and HDAC1 and represses transcription from E2Fresponsive promoters. Nat. Genet. 25: 338-342.

Rountree, M.R., Bachman, K.E., and Baylin, S.B. 2000. DNMT1 binds HDAC2 and a new co-repressor, DMAP1, to form a complex at replication foci. Nat. Genet. 25: 269-277.

Sengupta, N. and Seto, E. 2004. Regulation of histone deacetylase activities. J. Cell. Biochem. 93: 57-67.

Shi, Y. and Mello, C. 1998. A CBP/p300 homolog specifies multiple differentiation pathways in Caenorhabditis elegans. Genes \& Dev. 12: 943-955.

Shi, Y., Lan, F., Matson, C., Mulligan, P., Whetstine, J.R., Cole, P.A., Casero, R.A., and Shi, Y. 2004. Histone demethylation mediated by the nuclear amine oxidase homolog LSD1. Cell 119: 941-953.

Strausberg, R.L., Feingold, E.A., Grouse, L.H., Derge, J.G., Klausner, R.D., Collins, F.S., Wagner, L., Shenmen, C.M., Schuler, G.D., Altschul, S.F., et al. 2002. Generation and initial analysis of more than 15,000 full-length human and mouse cDNA sequences. Proc. Natl. Acad. Sci. 99: 1689916903.

Sumiyoshi, E., Sugimoto, A., and Yamamoto, M. 2002. Protein 
phosphatase 4 is required for centrosome maturation in mitosis and sperm meiosis in C. elegans. J. Cell Sci. 115: 14031410.

Takami, Y. and Nakayama, T. 2000. N-terminal region, C-terminal region, nuclear export signal, and deacetylation activity of histone deacetylase- 3 are essential for the viability of the DT40 chicken B cell line. J. Biol. Chem. 275: 1619116201.

Taunton, J., Hassig, C.A., and Schreiber, S.L. 1996. A mammalian histone deacetylase related to the yeast transcriptional regulator Rpd3p. Science 272: 408-411.

Thiagalingam, S., Cheng, K.H., Lee, H.J., Mineva, N., Thiagalingam, A., and Ponte, J.F. 2003. Histone deacetylases: Unique players in shaping the epigenetic histone code. Ann. NY Acad. Sci. 983: 84-100.

Tong, J.K., Hassig, C.A., Schnitzler, G.R., Kingston, R.E., and Schreiber, S.L. 1998. Chromatin deacetylation by an ATPdependent nucleosome remodelling complex. Nature 395: 917-921.

Tsai, S.C. and Seto, E. 2002. Regulation of histone deacetylase 2 by protein kinase CK2. J. Biol. Chem. 277: 31826-31833.

Tsai, S.C., Valkov, N., Yang, W.M., Gump, J., Sullivan, D., and Seto, E. 2000. Histone deacetylase interacts directly with DNA topoisomerase II. Nat. Genet. 26: 349-353.

Tussie-Luna, M.I., Bayarsaihan, D., Seto, E., Ruddle, F.H., and Roy, A.L. 2002. Physical and functional interactions of histone deacetylase 3 with TFII-I family proteins and PIASxbeta. Proc. Nat1. Acad. Sci. 99: 12807-12812.

Underhill, C., Qutob, M.S., Yee, S.P., and Torchia, J. 2000. A novel nuclear receptor corepressor complex, N-CoR, contains components of the mammalian SWI/SNF complex and the corepressor KAP-1. J. Biol. Chem. 275: 40463-40470.

Urnov, F.D., Yee, J., Sachs, L., Collingwood, T.N., Bauer, A., Beug, H., Shi, Y.B., and Wolffe, A.P. 2000. Targeting of N$\mathrm{CoR}$ and histone deacetylase 3 by the oncoprotein $\mathrm{v}$-erbA yields a chromatin infrastructure-dependent transcriptional repression pathway. EMBO J. 19: 4074-4090.

Vaziri, H., Dessain, S.K., Ng Eaton, E., Imai, S.I., Frye, R.A., Pandita, T.K., Guarente, L., and Weinberg, R.A. 2001. hSIR2(SIRT1) functions as an NAD-dependent p53 deacetylase. Cell 107: 149-159.

Wada, T., Miyata, T., Inagi, R., Nangaku, M., Wagatsuma, M., Suzuki, D., Wadzinski, B.E., Okubo, K., and Kurokawa, K. 2001. Cloning and characterization of a novel subunit of protein serine/threonine phosphatase 4 from mesangial cells. J. Am. Soc. Nephrol. 12: 2601-2608.

Wade, P.A., Jones, P.L., Vermaak, D., and Wolffe, A.P. 1998. A multiple subunit $\mathrm{Mi}-2$ histone deacetylase from Xenopus laevis cofractionates with an associated Snf2 superfamily ATPase. Curr. Biol. 8: 843-846.

Walsh, A.H., Cheng, A., and Honkanen, R.E. 1997. Fostriecin, an antitumor antibiotic with inhibitory activity against serine/threonine protein phosphatases types 1 (PP1) and 2A (PP2A), is highly selective for PP2A. FEBS Lett. 416: 230234.

Weiss, C., Schneider, S., Wagner, E.F., Zhang, X., Seto, E., and Bohmann, D. 2003. JNK phosphorylation relieves HDAC3dependent suppression of the transcriptional activity of cJun. EMBO J. 22: 3686-3695.

Wen, Y.D., Perissi, V., Staszewski, L.M., Yang, W.M., Krones, A., Glass, C.K., Rosenfeld, M.G., and Seto, E. 2000. The histone deacetylase-3 complex contains nuclear receptor corepressors. Proc. Natl. Acad. Sci. 97: 7202-7207.

Wen, Y.D., Cress, W.D., Roy, A.L., and Seto, E. 2003. Histone deacetylase 3 binds to and regulates the multifunctional transcription factor TFII-I. J. Biol. Chem. 278: 1841-1847.
Yang, X.J. and Seto, E. 2003. Collaborative spirit of histone deacetylases in regulating chromatin structure and gene expression. Curr. Opin. Genet. Dev. 13: 143-153.

Yang, W.M., Inouye, C., Zeng, Y., Bearss, D., and Seto, E. 1996. Transcriptional repression by YY1 is mediated by interaction with a mammalian homolog of the yeast global regulator RPD3. Proc. Natl. Acad. Sci. 93: 12845-12850.

Yang, W.M., Yao, Y.L., Sun, J.M., Davie, J.R., and Seto, E. 1997. Isolation and characterization of cDNAs corresponding to an additional member of the human histone deacetylase gene family. J. Biol. Chem. 272: 28001-28007.

Yang, W.M., Tsai, S.C., Wen, Y.D., Fejer, G., and Seto, E. 2002. Functional domains of histone deacetylase-3. J. Biol. Chem. 277: 9447-9454.

Yeh, P.Y., Yeh, K.H., Chuang, S.E., Song, Y.C., and Cheng, A.L. 2004. Suppression of MEK/ERK signaling pathway enhances cisplatin-induced NF- $\mathrm{B}$ activation by protein phosphatase 4-mediated NF- $\mathrm{B}$ p65 Thr dephosphorylation. J. Biol. Chem. 279: 26143-26148.

Yoon, H.G., Chan, D.W., Huang, Z.Q., Li, J., Fondell, J.D., Qin, J., and Wong, J. 2003. Purification and functional characterization of the human N-CoR complex: The roles of HDAC3, TBL1 and TBLR1. EMBO I. 22: 1336-1346.

Zhang, Y., LeRoy, G., Seelig, H.P., Lane, W.S., and Reinberg, D. 1998. The dermatomyositis-specific autoantigen Mi2 is a component of a complex containing histone deacetylase and nucleosome remodeling activities. Cell 95: 279-289.

Zhang, J., Kalkum, M., Chait, B.T., and Roeder, R.G. 2002. The N-CoR-HDAC3 nuclear receptor corepressor complex inhibits the JNK pathway through the integral subunit GPS2. Mol. Cell 9: 611-623.

Zhang, X., Wharton, W., Yuan, Z., Tsai, S.C., Olashaw, N., and Seto, E. 2004. Activation of the growth-differentiation factor 11 gene by the histone deacetylase (HDAC) inhibitor trichostatin A and repression by HDAC3. Mol. Cell. Biol. 24: 5106-5118.

Zhou, G., Mihindukulasuriya, K.A., MacCorkle-Chosnek, R.A., Van Hooser, A., Hu, M.C., Brinkley, B.R., and Tan, T.H. 2002. Protein phosphatase 4 is involved in tumor necrosis factor- $\alpha$-induced activation of $\mathrm{c}$-Jun $\mathrm{N}$-terminal kinase. $J$. Biol. Chem. 277: 6391-6398.

Zhou, G., Boomer, J.S., and Tan, T.H. 2004. Protein phosphatase 4 is a positive regulator of hematopoietic progenitor kinase 1. J. Biol. Chem. 279: 49551-49561. 


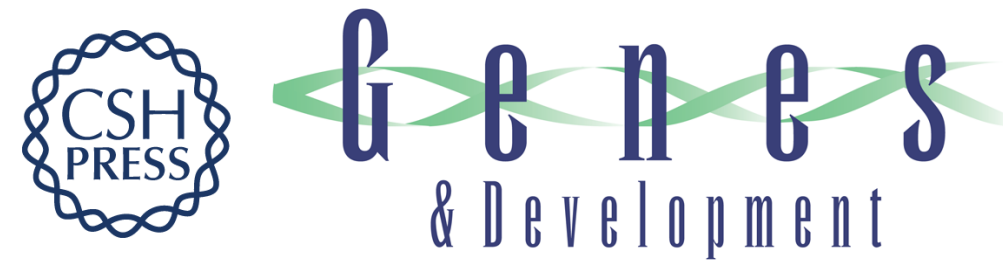

\section{Histone deacetylase 3 (HDAC3) activity is regulated by interaction with protein serine/threonine phosphatase 4}

Xiaohong Zhang, Yukiyasu Ozawa, Heehyoung Lee, et al.

Genes Dev. 2005, 19:

Access the most recent version at doi:10.1101/gad.1286005

$\begin{array}{ll}\text { References } & \text { This article cites } 87 \text { articles, } 45 \text { of which can be accessed free at: } \\ \text { http://genesdev.cshlp.org/content/19/7/827.full.html\#ref-list-1 }\end{array}$

License

Email Alerting

Receive free email alerts when new articles cite this article - sign up in the box at the top Service right corner of the article or click here.

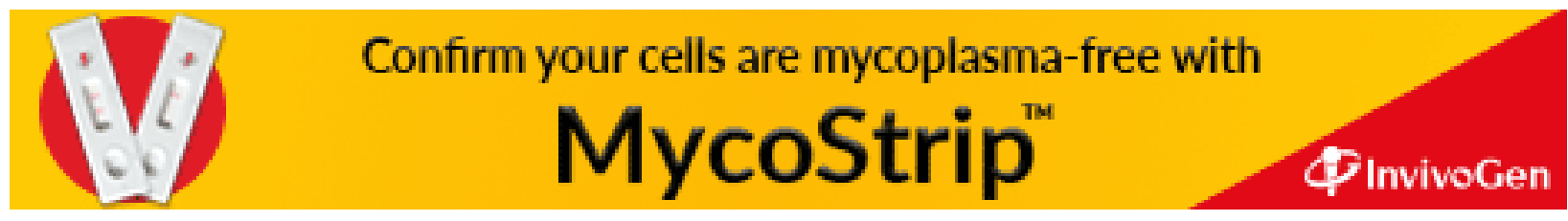

